\title{
Immobilized VO-Schiff Base Complex on Modified Graphene Oxide Nanosheets as an Efficient and Recyclable Heterogeneous Catalyst in Deep Desulfurization of Model Oil
}

\author{
Maryam Abdi, ${ }^{1}$ Abdollah Fallah Shojaei, ${ }^{2, \star}$ Mohammad Ghadermazi ${ }^{1}$ \\ and Zeinab Moradi-Shoeili ${ }^{2}$ \\ ${ }^{1}$ Department of Chemistry, Faculty of Science, University of Kurdistan, Sanandaj, Iran \\ ${ }^{2}$ Department of Chemistry, Faculty of Sciences, University of Guilan, P.O. Box 41335-1914, Rasht, Iran. \\ *Corresponding author: E-mail: a.f.shojaie@guilan.ac.ir,shoja47@gmail.com
}

Received: 08-04-2019

\begin{abstract}
New heterogeneous catalyst was synthesized via covalent anchoring of oxovanadium(IV) complex of 5,5'-dibromobis(salicyledene)diethylenetriamine ( $\mathrm{VO}[5-\mathrm{Br}($ Saldien) $]$ ) on the surface of chloro-modified graphene oxide (GO@ CTS). The structure of the catalyst was investigated using different characterization techniques such as XRD, SEM, EDX, FT-IR, TG, DTA and ICP-AES analyses. The synthesized heterogeneous oxovanadium(IV) was an efficient catalyst for high yield and selective oxidation desulfurization (ODS) of dibenzothiophene (DBT) as a model oil using $\mathrm{H}_{2} \mathrm{O}_{2}$ as oxidant and formic acid as a promoter. The effects of the catalyst mass, reaction temperature and time, formic acid/ $\mathrm{H}_{2} \mathrm{O}_{2}$ ratio and molar ratio of $\mathrm{H}_{2} \mathrm{O}_{2}$ to the total amount of sulfur $(\mathrm{O} / \mathrm{S})$ on oxidation desulfurization activity were investigated. Moreover, the prepared catalyst can be easily separated from the reaction mixture and reused six times without a significant loss of catalytic activity and selectivity.
\end{abstract}

Keywords: Vanadium; desulfurization; graphene oxide; heterogeneous catalyst.

\section{Introduction}

Growing energy demand will be accompanied by growing greenhouse gas (GHG) emissions e.g. $\mathrm{CO}_{2}$ with an impact on climate change and non-GHG emissions e.g. $\mathrm{NO}_{\mathrm{x}}, \mathrm{SO}_{2}$, volatile organic compounds and particulate materials with an impact on local air quality. ${ }^{1}$ In addition to environmental pollution, these emissions have been threatening human health. ${ }^{2}$ The combustion of transportation fuels contaminated by sulfur compounds results in the emission of $\mathrm{SO}_{\mathrm{x}}$, which is responsible for the photochemical smog, acid rain, corrosion, etc. And also contributes to global warming. ${ }^{3}$ These concerns have driven the need to reduce sulfur emissions to the atmosphere through the regulation of sulfur in transportation fuels. ${ }^{4}$ Thus desulfurization of fuels has attracted much attention due to the environmental pressures to reduce the sulfur content in recent years. ${ }^{5}$ Petroleum fractions contain considerable amounts of benzothiophene (BT), dibenzothio- phene (DBT), and their alkyl-substituted derivatives. These polyaromatic sulfur molecules are low reactive toward the hydrogenolysis of the C-S bond and, as a consequence, are difficult to remove by conventional hydrodesulfurization reactions (HDS), ${ }^{6,7}$ To overcome the disadvantages of HDS, various methods, such as adsorptive desulfurization, ${ }^{8}$ extractive desulfurization, oxidative desulfurization (ODS $)^{9-11}$ and biodesulfurization ${ }^{12}$ were investigated to produce ultra clean fuels. Among these techniques, ODS is regarded as a promising method to obtain low levels of sulfur in fuel oils. ${ }^{13-17}$ The ODS processes usually include two successive steps: oxidation of organosulfur compounds to less harmful polar derivatives (sulfoxides and sulfones) and elimination of these compounds by extraction into a polar solvent or onto a sorbent. ${ }^{18,19}$ Homogeneous and heterogeneous catalysis systems using molecular oxygen, hydrogen peroxide, tert-butyl hydroperoxide, and peroxyorganic acids as oxidants are capable of desulfurizing diesel fuels under mild reaction condi- 
tions $\left(50-90{ }^{\circ} \mathrm{C}\right) \cdot{ }^{16,18-22}$ However, the commercialization of these processes will need optimization of the oxidant, the catalyst, and the method for isolating the oxidized products of heterocyclic sulfur compounds from the petroleum fractions. ${ }^{22}$ The oxidation of organosulfur compounds occurs in the presence of metal catalysts, mostly transition metals, in high oxidation states, such as Mo (IV), Ti (IV), V (V),W (IV) and Re. ${ }^{23-25}$ Vanadium, among transition metals, is relatively cheap and readily available. Moreover, due to the interesting chemical properties of vanadium such as selectivity, reactivity and stereoselectivity, oxidovanadium complexes are of special interest as a catalyst in oxidation of several organic compounds. ${ }^{20} \mathrm{~A}$. Coletti et al. reported the application of oxovanadium(V) species, ligated with substituted salicylaldehyde Schiff bases and o-phenylendiamine or 1,2-ethanediamine, as catalysts for oxidation of sulfides in the presence of $\mathrm{H}_{2} \mathrm{O}_{2} \cdot{ }^{21}$ However, because of their homogeneous nature, these catalysts are difficult to separate from the reaction mixture and thus, cannot be recycled. Covalent attachment is known as the most effective method for anchoring the homogeneous metal complexes on the surface of various supports. Maurya et al. reported two oxidovanadium(IV) and dioxidovanadium $(\mathrm{V})$ complexes grafted on polymer support for the oxidation of thiophene derivatives present in model fuel diesel. Results showed that the immobilization of homogeneous complexes onto the polystyrene support enhances their stability and catalytic reactions are heterogeneous in nature. ${ }^{26}$ Ogunlaja and coworkers reported a continuous flow system for oxidative desulfurization of refractory organosulfur compounds by two oxovanadium(IV) polymer supported catalysts. ${ }^{23}$ Graphene oxide (GO) has attracted considerable attention as one of the most promising supports to immobilize homogeneous vanadium complexes. ${ }^{27}$ Mungse et al. reported the covalent anchoring of an oxovanadium Schiff base complex onto GO nanosheets for the oxidation of various alcohols, diols, and a-hydroxyketones to carbonyl compounds using tert-butylhydroperoxide (TBHP) as an oxidant. ${ }^{28}$ Verma et al. reported that oxovanadium Schiff base supported graphene oxide exhibited a higher catalytic efficiency than the homogeneous vanadyl acetylacetonate for epoxidation of fatty acids and esters. ${ }^{29}$ Moreover, Hajjar and coworkers reported the application of nano-graphene sheet supported Co and Mo species in the HDS process. They clearly showed that $\mathrm{Co}-\mathrm{Mo} /$ graphene catalysts were more active than the industrial $\mathrm{Co}-\mathrm{Mo} / \gamma-\mathrm{Al}_{2} \mathrm{O}_{3}$ catalysts. ${ }^{30}$ In the present work, the synthesis of heterogeneous catalyst by immobilization of $\mathrm{VO}[5-\mathrm{Br}$ (Saldien)] complex on the modified graphene oxide as support (GO@5-Br(Saldien)VO) is described. In addition, this report includes the results of the investigation of the catalytic performance of GO@5-Br(Saldien)VO in ODS reactions. The heterogeneous catalyst proved to be efficient for the selective oxidation of DBT with $\mathrm{H}_{2} \mathrm{O}_{2}$ promoted by formic acid. The effects of the catalyst mass, reaction temperature and time, formic acid $/ \mathrm{H}_{2} \mathrm{O}_{2}$ ratio, and the $\mathrm{O} / \mathrm{S}$ ratio (molar ratio of $\mathrm{H}_{2} \mathrm{O}_{2}$ to the total amount of sulfur in an initial solution of DBT) on ODS activity was investigated. Moreover, the prepared catalyst was successfully reused for six runs without a significant loss in catalytic activity.

\section{Experimental}

\section{1. Materials and Characterization}

All reagents and materials used in this work were obtained from Fluka, Aldrich or Merck and were used without further purification. All solvents were reagent grade and dried and distilled before use, according to the standard procedures. X-ray diffraction (XRD) patterns were recorded on a MPD diffractometer of X'pert with $\mathrm{Cu}-\mathrm{Ka}$ radiation $(\mathrm{l}=1.5418 \AA)$ under the conditions of $40 \mathrm{kV}$ and $30 \mathrm{~mA}$. SEM images were recorded using FESEM-TESCAN MIRA3. Fourier transforms infrared (FT-IR) spectra of $\mathrm{KBr}$ disks were measured on a VERTEX70 model BRUKER FT-IR spectrophotometer. Thermogravimetric analysis (TGA) was carried out under $\mathrm{N}_{2}$ flow while gradually increasing the temperature with a rate of $10^{\circ} \mathrm{C} \mathrm{min}^{-1}$, using a STA PT-1000 LINSEIS. The elemental analysis of the samples was done by energy dispersive $\mathrm{X}$-ray spectroscopy (EDX, TSCAN). The progress of model reactions was recorded on a CARY 100 Bio VARIAN UV-vis spectrophotometer. For determining vanadium loading in the synthesized catalyst, ICP-AES analysis was carried out by an inductively coupled plasma atomic emission spectroscopy (ICP-AES) on a Perkin-Elmer AA-300 spectrophotometer.

\section{2. Synthesis of $5,5^{\prime}$-Br-Bissalicylidendiethyl Enetriamine Ligand 5-Br(Saldien)}

In a typical procedure, one molecular equivalent of diethylenetriamine (dien) $(0.1 \mathrm{~mL}, 1 \mathrm{mmol})$ was added to two molecular equivalents of 5-bromosalicylaldehyde $(0.402 \mathrm{~g}, 2 \mathrm{mmol})$ dissolved in absolute ethanol at room temperature. After stirring for $15 \mathrm{~min}$, the volume of the solution was reduced until only an oil remained which was identified via FT-IR spectroscopy. ${ }^{31}$

\section{3. Synthesis of Chloro-Functionalized Graphene Oxide (GO@CTS)}

In a typical procedure, $250 \mathrm{~mL}$ dry toluene was added into a two-necked flask and then $1.0 \mathrm{~g} \mathrm{GO}$ was dispersed using ultrasound. Afterward, $3 \mathrm{~mL} 3$-chloroopropyltrimethoxysilane (CTS) diluted in $20 \mathrm{~mL}$ dry toluene was added to the stirred solution. The reaction mixture was refluxed at $110^{\circ} \mathrm{C}$ under $\mathrm{N}_{2}$ atmosphere for $48 \mathrm{~h}$. The mixture was filtered and washed with a large amount of toluene and ethanol to remove excess CTS and then dried in the oven at $70^{\circ} \mathrm{C} .{ }^{32}$ 


\section{4. Immobilization of $\mathrm{VO}$ [5-Br(Saldien)] Complex onto the GO@CTS}

To a suspension of freshly dried GO@CTS (2 g) in dry toluene $(40 \mathrm{~mL})$, a solution of $5-\mathrm{Br}$ (saldien) ligand (1 g) in dry toluene $(10 \mathrm{~mL})$ and triethylamine $(0.5 \mathrm{~mL})$ was added and the resulting solution was refluxed for $12 \mathrm{~h}$. After this step, the resulted product was separated and then washed with anhydrous toluene several times to remove the unreacted $5-\mathrm{Br}$ (saldien) ligand adsorbed on the surface of GO@CTS and dried under vacuum at $70{ }^{\circ} \mathrm{C}$. Then, 5-Br(saldien)-functionalized GO@CTS (1 g) was dispersed in $250 \mathrm{~mL}$ dry ethanol by using ultrasonication. In the subsequent step, $\mathrm{VO}(\mathrm{acac})_{2}(0.1 \mathrm{~g})$ was added to the stirring mixture. This mixture was refluxed for $3 \mathrm{~h}$. The final product was filtered and washed with dry ethanol and dried under vacuum overnight.

\section{5. Catalytic Activity Tests (Oxidation of DBT)}

The oxidative desulfurization experiments were optimized using the model oil, $500 \mathrm{ppm}$ DBT in $\mathrm{n}$-heptane. The desired amounts of catalyst and $5 \mathrm{~mL}$ acetonitrile were added into $5 \mathrm{~mL}$ model oil containing $500 \mathrm{ppm}$ DBT in a twonecked flask, equipped with a condenser, agitator and thermometer. Prior to the catalytic reaction the mixture was magnetic stirring at a constant speed for $30 \mathrm{~min}$ to ensure an adsorption-desorption equilibration of the system. Afterward, a specific amount of $\mathrm{H}_{2} \mathrm{O}_{2}$ was added to the system. The system was continuously stirred at a constant temperature using a water bath at atmospheric pressure.

\section{Results and Discussion}

The schematic representation for the synthesis of heterogeneous GO@5- $\mathrm{Br}$ (Saldien)VO complex is shown in Fig.1. Heterogeneous catalyst was successfully obtained in a three-step procedure. The first step involves the functionalization $\mathrm{GO}$ by 3-chloropropyltrimethoxysilane. Then the ligand was attached to GO@CTS using nucleophilic displacement of cholorine by the basic amino group of the ligand. Finally, $\mathrm{VO}(\mathrm{acac})_{2}$ was added to the stirring mixture of 5-Brsaldien functionalized GO@CTS which affords GO@5-Br(Saldien)VO.

\section{1. Spectroscopic Characterization of GO@5-Br(Saldien)VO Heterogeneous Catalyst}

Fig. 2 shows the FT-IR spectra of the GO, GO@CTS, GO@5-Br(Saldien) and covalently attached salen complex catalyst, GO@5-Br(Saldien)VO. Characteristic bands of

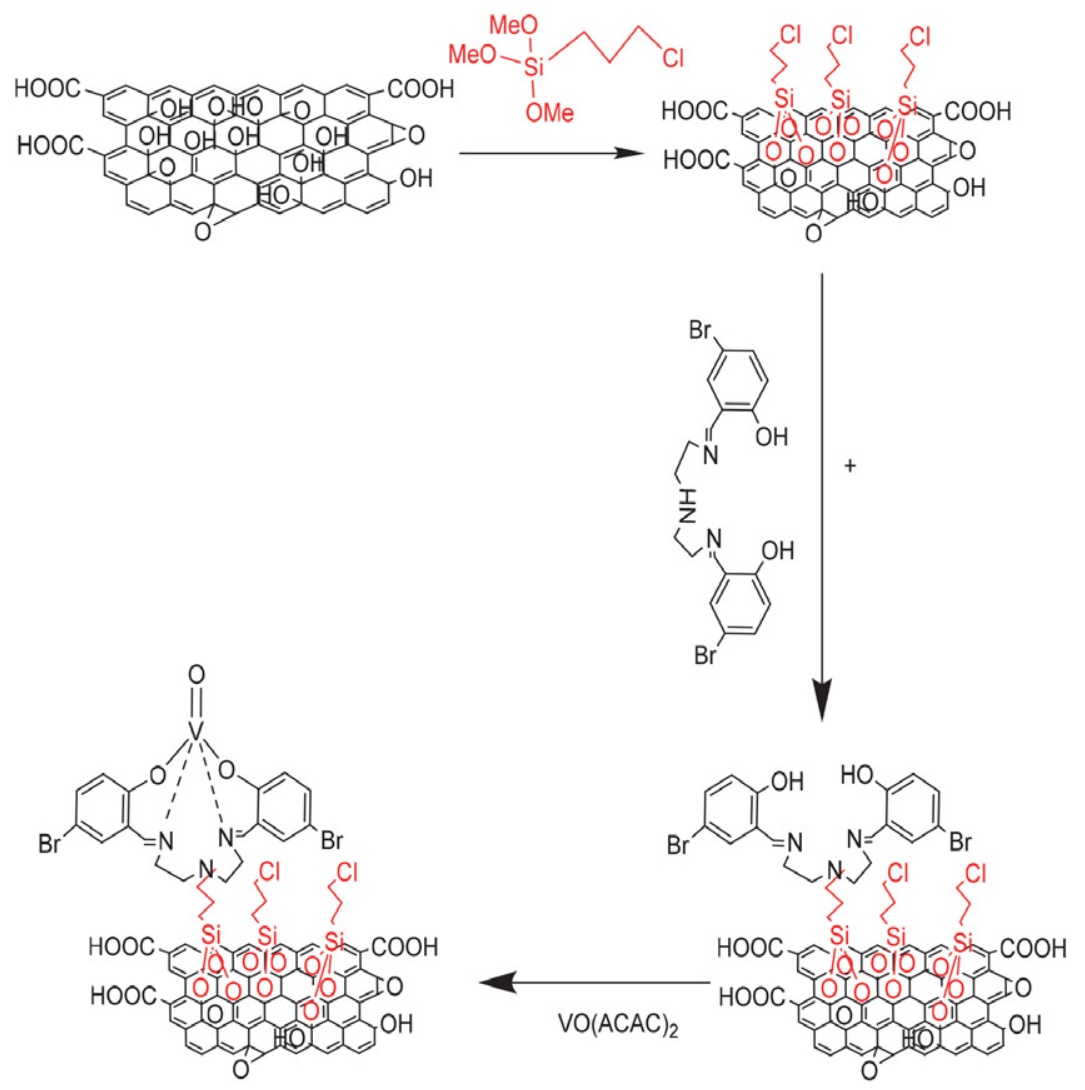

Fig. 1. Schematic representation for the synthesis of GO@5-Br(Saldien)VO heterogeneous catalyst. 
the pure GO support (Fig. 2a) appeared in a. 3421, 1723, $1623,1033 \mathrm{~cm}^{-1}$ corresponding to the stretching modes of $\mathrm{O}-\mathrm{H}, \mathrm{C}=\mathrm{O}, \mathrm{C}=\mathrm{C}$, and $\mathrm{C}-\mathrm{O}-\mathrm{C}$ moieties, respectively. ${ }^{33}$ The presence of numerous hydroxyl groups on the GO provides active sites for the bonding between GO sheets and CTS. The FT-IR spectrum of GO@CTS has been exhibited in Fig. 2b. The absorption peak at $1032 \mathrm{~cm}^{-1}$ represents the $\mathrm{Si}-\mathrm{O}-\mathrm{C}$ stretching vibration and the vibrational bands at $2926 \mathrm{~cm}^{-1}$ and $2854 \mathrm{~cm}^{-1}$ are attributed to $\mathrm{CH}_{2}$ groups. Also, the presence of a peak at $695 \mathrm{~cm}^{-1}$ represents the C$\mathrm{Cl}$ bond stretching, which indicated the successful coating of CTS onto the graphene oxide through chemical bonding. ${ }^{34}$ Comparing the FT-IR spectra of the covalently attached GO@5-Br(Saldien)VO on the choloro-modified graphene oxide with that of the graphene oxide and GO@ CTS revealed some new weak peaks in the range of 1600 $1200 \mathrm{~cm}^{-1}$ due to $\mathrm{C}-\mathrm{O}, \mathrm{C}-\mathrm{N}$ and aromatic ring vibrations. The FT-IR spectrum of GO@5-Br(Saldien) shows a new peak at around $1611 \mathrm{~cm}^{-1}$, attributed to $\mathrm{C}=\mathrm{N}$ stretching due to the Schiff base indicating that the salen ligand was successfully immobilized on GO. The sharp band at 1611 $\mathrm{cm}^{-1}$ (Fig. 2c) which was assigned to $\gamma(\mathrm{C}=\mathrm{N})$ has shifted to the $1605 \mathrm{~cm}^{-1}$ range (Fig. 2d) in the spectra of the complex. This observation indicates the coordination of nitrogen to the vanadium, which is in agreement with the literature values. ${ }^{35}$ Furthermore ICP-AES analysis of the covalent attachment of the oxovanadium(IV) complex on modified graphene oxide also indicates the successful introduction of the metal ion. The loading of vanadium in the synthesized catalyst was found to be $0.39 \mathrm{mmol} \mathrm{g}^{-1}$.

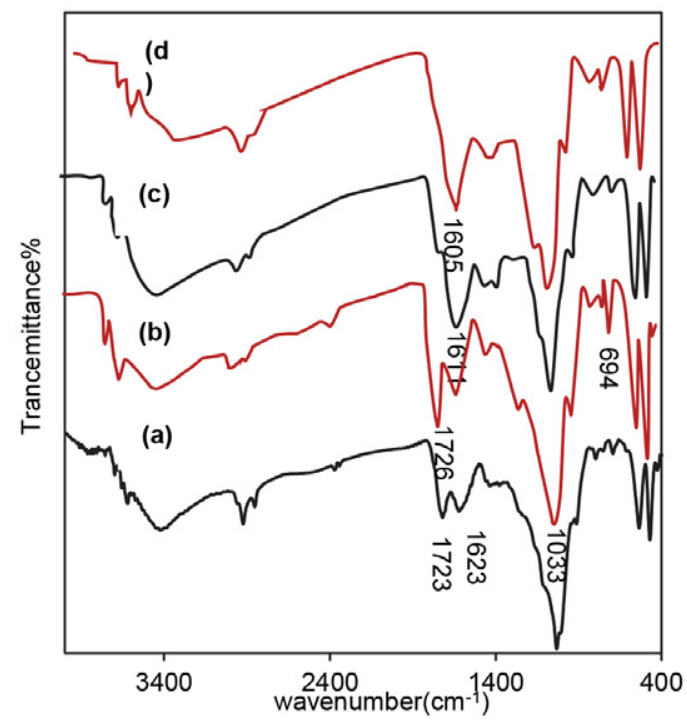

Fig. 2. FT-IR spectra of: (a) GO; (b) GO@CTS; (c) GO@5-Br(Saldien) (d) GO@5-Br(Saldien)VO.

Fig. 3 shows the XRD patterns of GO and GO@ $5-\mathrm{Br}$ (Saldien)VO. The peak at around $11.8^{\circ}$ can be attributed to the (001) reflection of graphene oxide, indicat- ing the oxygen species inserted into the graphitic layers. After the surface covalent functionalization of GO with CTS, coupling process and final production of the GO@5-Br(Saldien)VO catalyst, the diffraction peak at $2 \theta$ $=11.8^{\circ}$ was disappeared compared to GO and another broad diffraction peak of graphite at $2 \theta=23.77^{\circ}(002)$ appeared, indicating that the major oxygen containing groups of GO have been successfully functionalized with oxovanadium complex. ${ }^{29}$

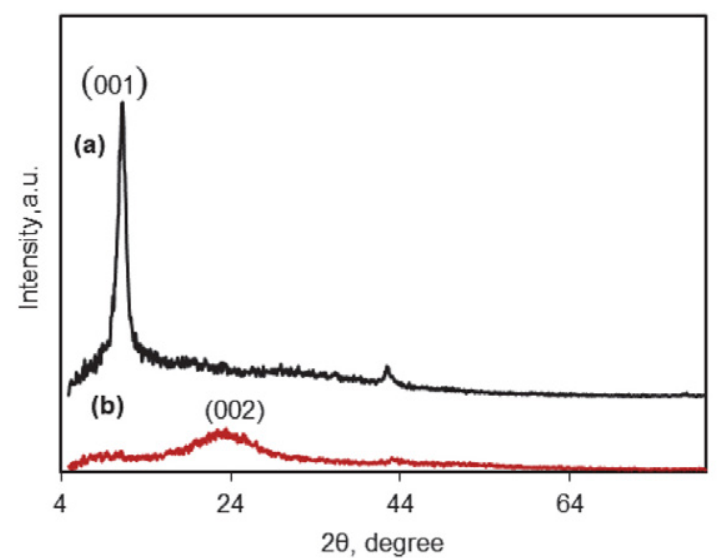

Fig. 3. XRD pattern of (a) GO (b) GO@5-Br(Saldien)VO.

The SEM images of GO and GO@5-Br(Saldien)VO are shown in Fig. $4 \mathrm{a}$ and $4 \mathrm{~b}$, respectively. It can be seen that GO and GO@5-Br(Saldien)VO have a similar morphology composed of two-dimensional nanosheets with a wavelike flexible and ultrathin sheet structure. ${ }^{36}$ To provide further information about the elemental composition of the GO@5-Br(Saldien)VO, the product was characterized by energy dispersive X-Ray (EDX) analysis (Fig. 5). The results clearly demonstrated the presence of vanadium in the synthesized heterogeneous catalyst, GO@5-Br(Saldien)VO.

The TG/DTA curves of GO and GO@5-Br(Saldien) VO are depicted in Fig. 6. The TG curve corresponding to the graphene oxide exhibited a typical three-step weight loss processes in the range of 31 to $700{ }^{\circ} \mathrm{C}$ under $\mathrm{N}_{2}$ flow (Fig. 6a), which can be assigned to the loss of physically adsorbed water and the decomposition of oxygen carrying functionalities, respectively. ${ }^{28} \mathrm{In}$ a first endothermic stage, GO started to decompose below $150{ }^{\circ} \mathrm{C}$ which can be ascribed by the removal of adsorbed water. The GO showed major weight losses within the temperature range from $150{ }^{\circ} \mathrm{C}$ to $250^{\circ} \mathrm{C}$ which can be attributed to $\mathrm{CO}, \mathrm{CO}_{2}$, and steam release from the most labile functional groups. ${ }^{37}$ Further increase of the temperature leads to weight loss for material, which ascribed to the bulk pyrolysis of the carbon skeleton. ${ }^{38}$ For GO@5-Br(Saldien)VO catalyst, the first weight loss at temperatures below $250{ }^{\circ} \mathrm{C}$ is due to the loss of physically adsorbed water and the decomposition of unused oxygen carrying functionalities, which have not interacted with CTS. ${ }^{28}$ The weight loss within the tempera- 

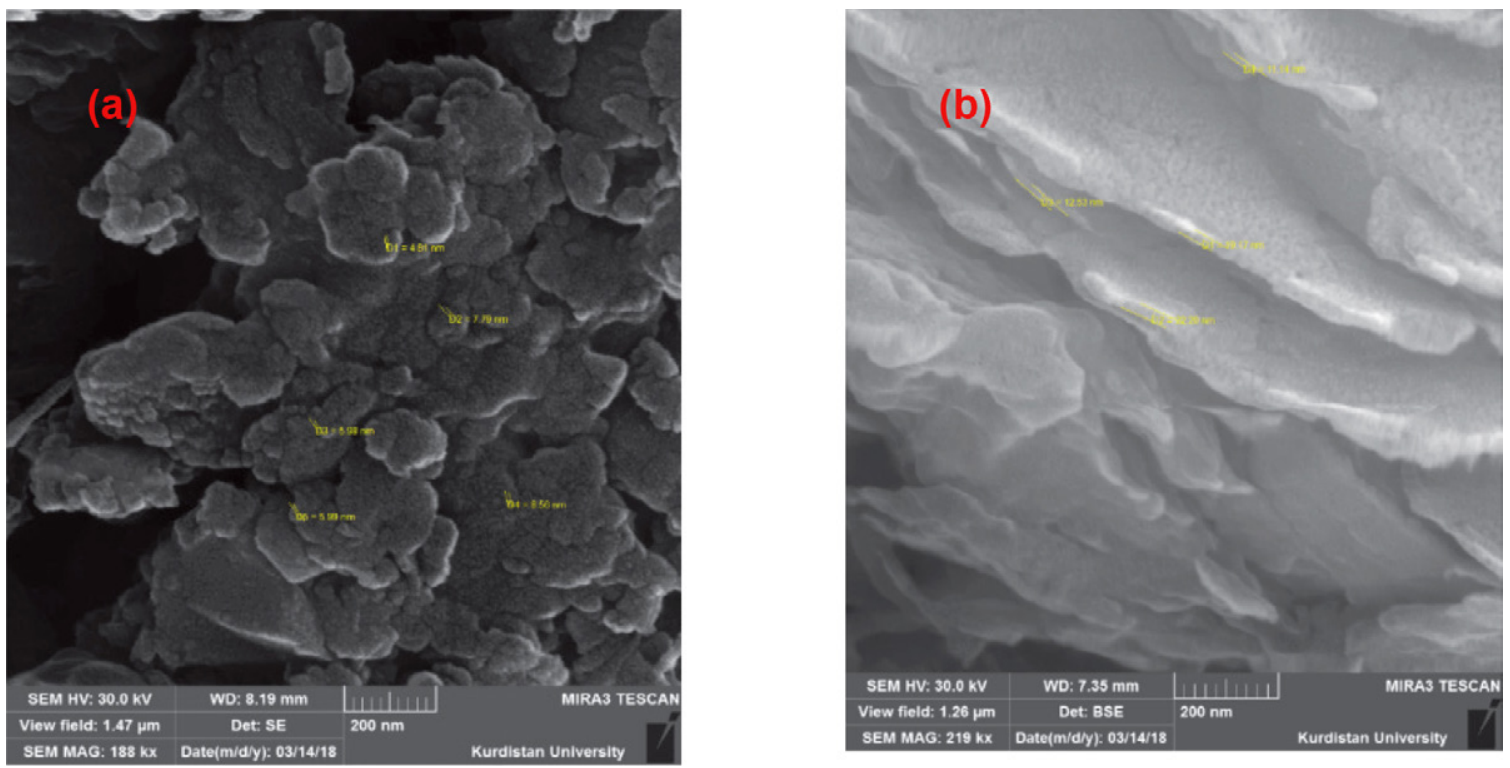

Fig. 4. SEM image of (a) GO, (b) GO@5-Br(Saldien)VO

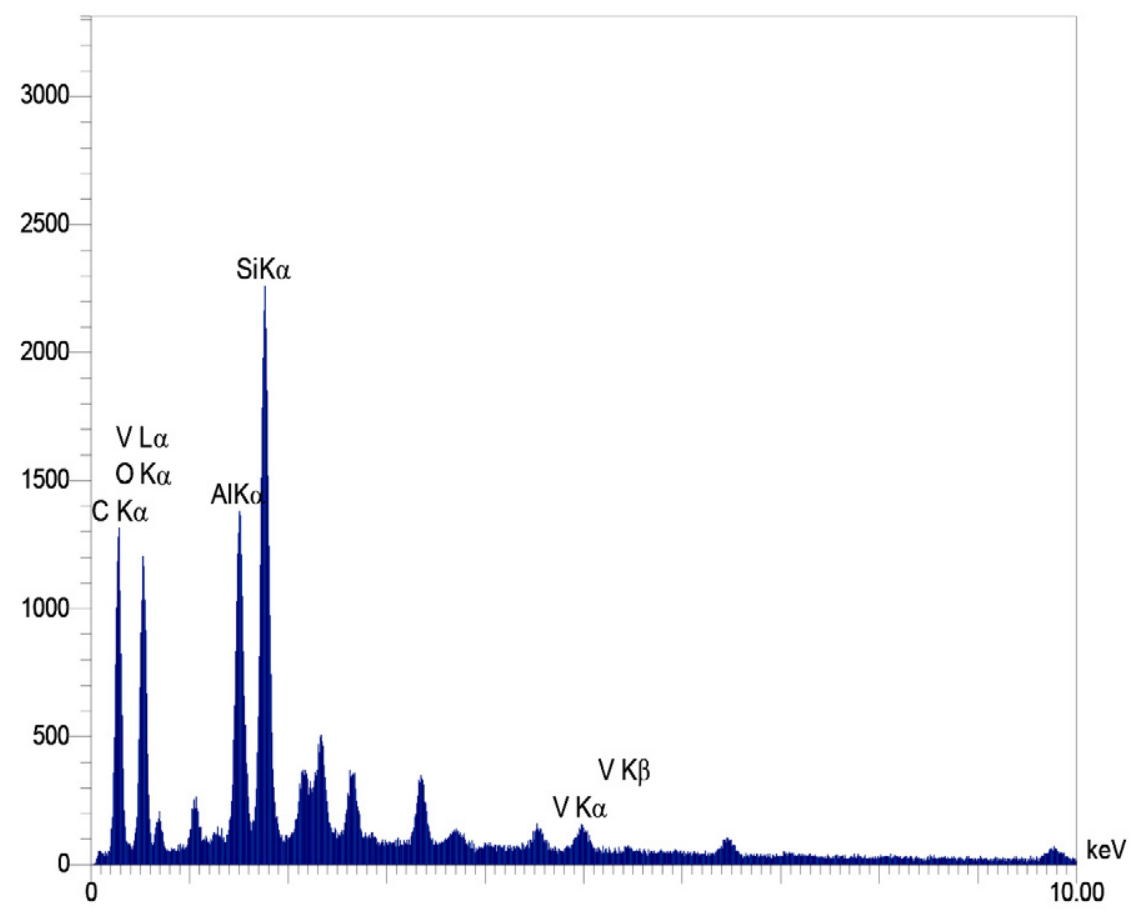

Fig. 5. EDX of GO@5-Br(Saldien)VO.

ture range of 250 to $450{ }^{\circ} \mathrm{C}$ is due to undigested oxygen carrying functionalities. Weight loss between $450-670{ }^{\circ} \mathrm{C}$ can probably be attributed to the decomposition of the Schiff base ligand. ${ }^{39}$

\section{2. Evaluation of Catalytic Activity}

The progress of the model reactions was monitored by UV-vis spectroscopy. The absorption at $286 \mathrm{~nm}$ was used to monitor the DBT concentration in the n-heptane phase. ${ }^{40}$ Fig. 7 shows the variations intensity of the UV-vis bands corresponding to DBT concentration, using GO@ (5- $\mathrm{Br}$, Saldien) VO as catalyst and $\mathrm{H}_{2} \mathrm{O}_{2}$ as oxidant under acidic condition. DBT concentration gradually decreases as the reaction time increases. Samples $(100 \mu \mathrm{L})$ were taken out from the $n$-heptane phase every 5 minutes during the first half hour of the experiment and every ten minutes afterward. In a typical analysis, $100 \mu \mathrm{L}$ of samples were di- 


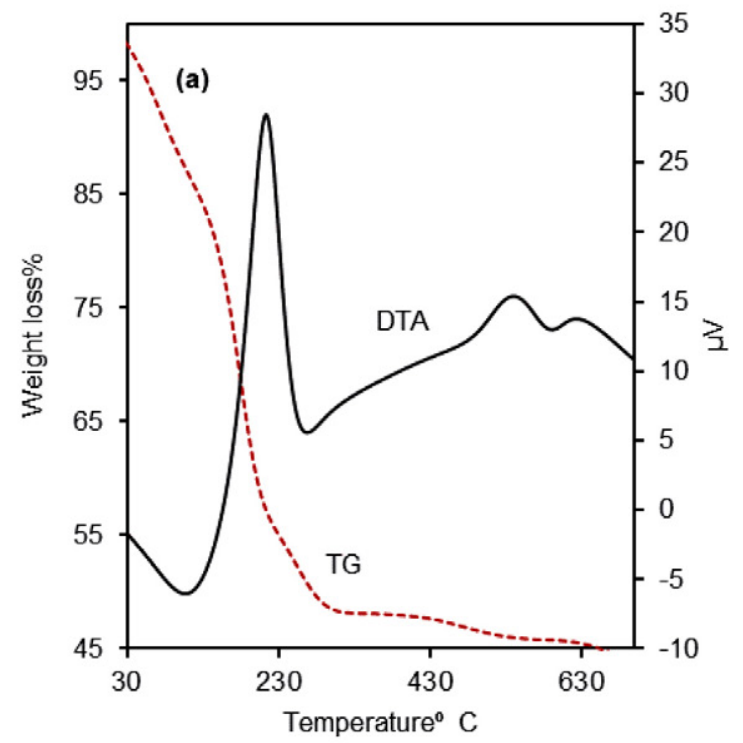

Fig. 6. TG and DTA curves of (a) GO (b) GO@5-Br(Saldien)VO.

luted with $5 \mathrm{ml}$ of absolute $n$-hexane (99.85\%). The DBT oxidation versus reaction time was determined according to the following equation:

$$
\mathrm{C}_{\mathrm{DBT}}(\%)=\frac{\left(\mathrm{c}_{0}-\mathrm{C}_{\mathrm{t}}\right)}{\mathrm{C}_{0}}
$$

The absorption was converted to the concentration through the standard curve, where $\mathrm{C}_{0}$ is the concentration at time zero and $\mathrm{C}_{\mathrm{t}}$ is the DBT concentration at time $\mathrm{t}$.

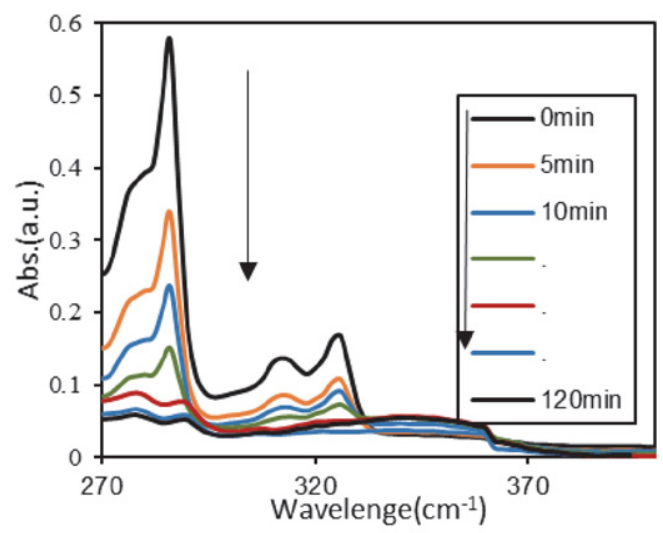

Fig. 7. Time dependent UV-visible spectral changes for oxidation of DBT (500ppm) using GO@(5- $\mathrm{Br}$,Saldien)VO as catalyst, $\mathrm{H}_{2} \mathrm{O}_{2}$ as oxidant and $5 \mathrm{ml}$ acetonitrile, under acidic condition at $60^{\circ} \mathrm{C}$.

\section{3. Influence of the Reaction Temperature on Catalytic Activity}

The reaction temperature greatly influences the activity of the catalyst and it is one of the greatest factors that could not be ignored in the desulfurization process. ${ }^{41}$ The effect of the temperature on the kinetics of oxidation of DBT was investigated in the temperature range of $30-70^{\circ} \mathrm{C}$.
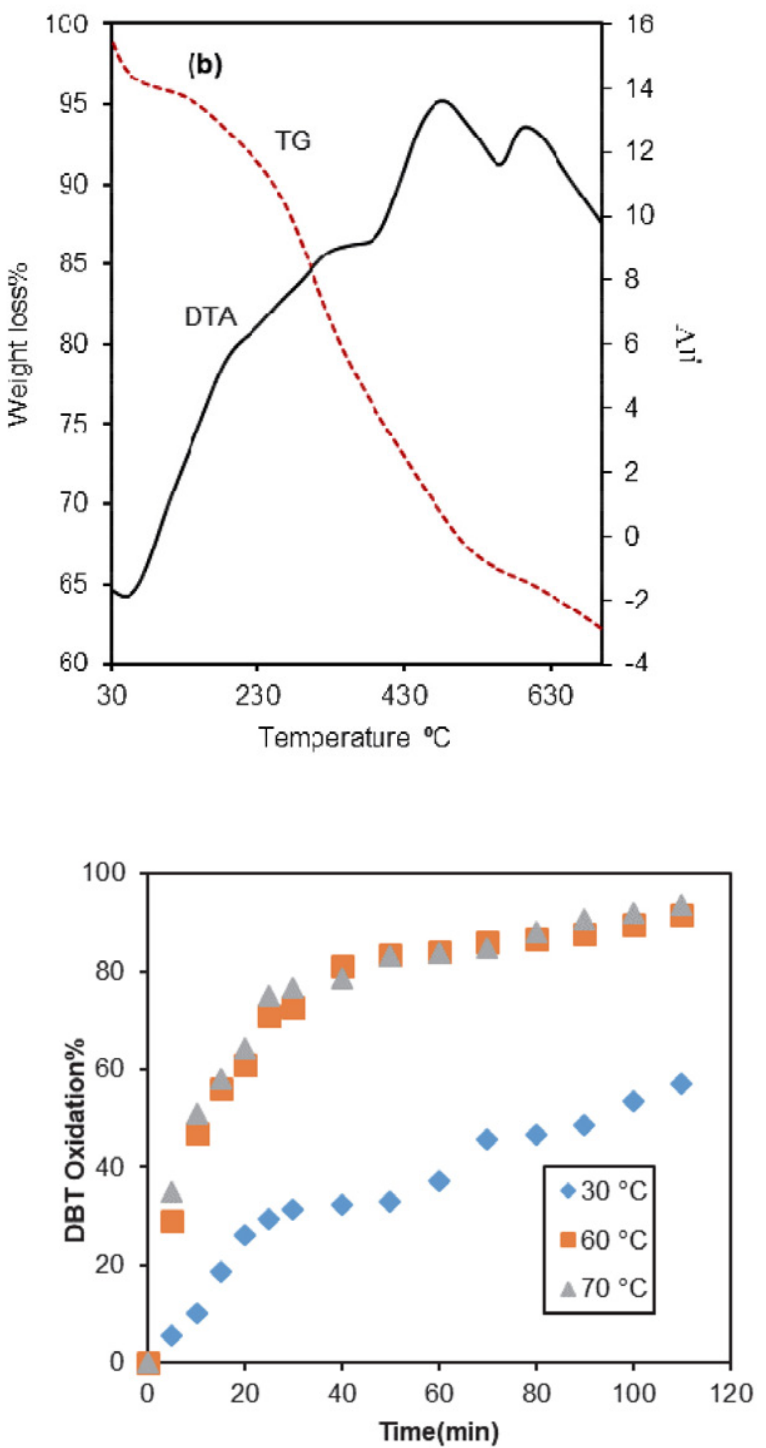

Fig. 8. Influence of the reaction temperature on DBT oxidation. The reaction conditions are as follows: reaction time: $120 \mathrm{~min}$, a catalyst mass $2.4 \mathrm{~g} / \mathrm{l}, \mathrm{O} / \mathrm{S}=6$ and acetonitrile $=5 \mathrm{~mL}$, a mixture of formic acid and hydrogen peroxide was added in the reaction mixture (formic acid $\left./ \mathrm{H}_{2} \mathrm{O}_{2}=1\right)$.

According to Fig. 8, the catalytic performance improved significantly when the reaction temperature was raised. The DBT conversion is only $57 \%$ at $30^{\circ} \mathrm{C}$ and increased to around $92 \%$ and $93 \%$ in $60{ }^{\circ} \mathrm{C}$ and $70{ }^{\circ} \mathrm{C}$, respectively. A rise in the reaction temperature from 30 to $60^{\circ} \mathrm{C}$ led to a remarkable increase in the reaction rate at every time of the reaction. However, this increase in the temperature from 60 to $70{ }^{\circ} \mathrm{C}$ was less marked. Thus, $60^{\circ} \mathrm{C}$ is chosen as an optimum temperature for the catalytic system.

\section{4. Effect of Catalyst Mass on DBT Oxidation}

The effect of the catalyst mass was evaluated over the range from $1.2 \mathrm{~g} / \mathrm{L}$ to $7.2 \mathrm{~g} / \mathrm{L}$ of the catalyst. Fig. 9 shows 
the effect of the catalyst mass in the oxidation of DBT. When the catalyst mass increases from 1.2 to $2.4 \mathrm{~g} / \mathrm{l}$, the DBT conversion increases, Increasing the catalyst mass lead to the increase in active sites which causes more amounts of DBT to be converted to dibenzothophene sulfone $\left(\mathrm{DBTO}_{2}\right){ }^{42}$ According to the Fig. 9, under identical conditions, only $33 \%$ of DBT is removed from the reaction by pure experiment. When $2.4 \mathrm{~g} / \mathrm{l}$ catalyst is employed, sulfur removal of DBT reaches $92 \%$ within $120 \mathrm{~min}$. However, increasing the catalyst mass to $7.2 \mathrm{~g} / \mathrm{L}$ apparently led to a decrease in activity. The decreased activity might be attributed to the poor dispersion of the catalyst solids within the reaction system. ${ }^{40}$ Therefore, the lower value of $2.4 \mathrm{~g} / \mathrm{L}$ was selected as the catalyst mass in the experiments.

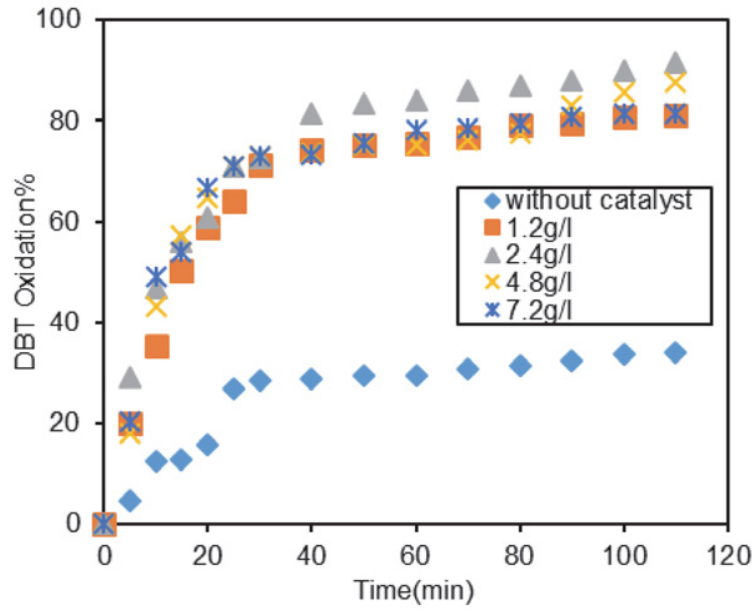

Fig. 9. Effect of catalyst mass on DBT oxidation, temperature $60^{\circ} \mathrm{C}$, reaction time $120 \mathrm{~min}$, and $\mathrm{O} / \mathrm{S}=6$, formic acid $/ \mathrm{H}_{2} \mathrm{O}_{2}=$ www1 and acetonitrile $=5 \mathrm{ml}$.

\section{5. Effect of the Amount of Hydrogen Peroxide in the Oxidation Process}

Detection of an optimum excess amount of $\mathrm{H}_{2} \mathrm{O}_{2}$ is an important agent that affects the efficiency and economy of the process. ${ }^{42}$ Theoretically, 2 moles of $\mathrm{H}_{2} \mathrm{O}_{2}$ are needed to completely oxidize 1 mole of the sulfur compound. ${ }^{43}$ However, usually, a bit higher amount of $\mathrm{H}_{2} \mathrm{O}_{2}$ is used in oxidative reaction because the undesirable thermal decomposition of $\mathrm{H}_{2} \mathrm{O}_{2}$ takes place simultaneously with the catalytic oxidation. ${ }^{44}$ With a lower $\mathrm{O} / \mathrm{S}$ molar ratio, sufficient intermediate active species is not available during the reaction and a more portion of DBT will remain unoxidized in the solvent. On the other hand, a high $\mathrm{O} / \mathrm{S}$ molar ratio is unfavorable because of wasting the oxidant and safety risks. ${ }^{44}$ Fig. 10 shows that the O/S molar ratio also had a significant influence on the oxidation DBT. An increase in O/S ratio from 2 to 6 results in a sharp increase in the overall desulfurization yield while the further increase from 8 to 10 has a slight effect. The current optimum value of 10 for the $\mathrm{O} / \mathrm{S}$ ratio seems to be ideal achieving a complete oxidative desulfurization yield.

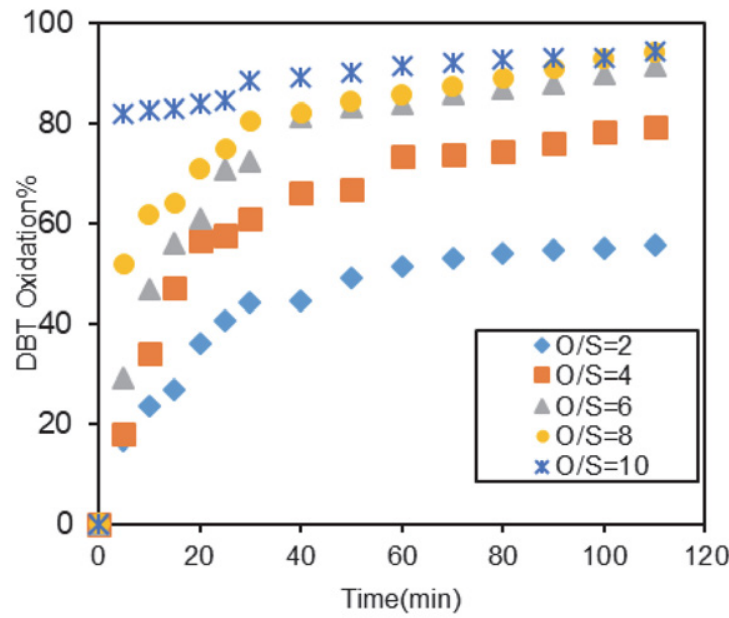

Fig. 10. Effect of the amount of hydrogen peroxide in the oxidation process. The reaction conditions are as follows: reaction time: 120 min, a catalyst Mass $2.4 \mathrm{~g} / \mathrm{l}$, acetonitrile $=5 \mathrm{ml}$, a mixture of formic acid and hydrogen peroxide was added in the reaction mixture (formic acid $/ \mathrm{H}_{2} \mathrm{O}_{2}=1$ ) and reaction temperature $60{ }^{\circ} \mathrm{C}$.

\section{6. Role of Formic Acid Promoter in the Oxidation Process}

It should be noted that during the ODS process, aliphatic peroxyacid as an oxygen supplier is obtained by the oxidation of the corresponding carboxylic acid with aqueous hydrogen peroxide. ${ }^{45}$ In turn, the interaction of peroxyformic acid with GO@5-Br(Saldien)VO generates active oxidizing species like peroxometallics and superoxometallics. ${ }^{46}$ This electrophilic active oxygen in oxo-peroxo metal species attacks the sulfur atom at a high electron density to form sulfones. ${ }^{47}$ They were also more stable than $\mathrm{H}_{2} \mathrm{O}_{2}$ as connecting to the surface metallic sites. ${ }^{48}$ Formation of peroxometallic complexes effectively inhibited the $\mathrm{H}_{2} \mathrm{O}_{2}$ decomposition to release gaseous oxygen before the reaction and thus improved the ODS efficien-

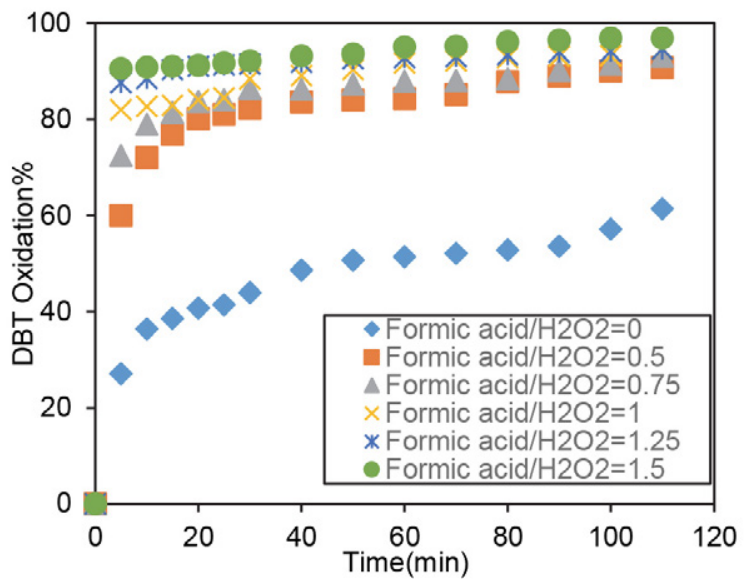

Fig. 11. Role of formic acid promoter in oxidation DBT, reaction time: $120 \mathrm{~min}$, a catalyst mass $2.4 \mathrm{~g} / \mathrm{l}, \mathrm{O} / \mathrm{S}=10$, acetonitrile $=5 \mathrm{ml}$, a mixture of formic acid and hydrogen peroxide was added in the reaction mixture (formic acid $/ \mathrm{H}_{2} \mathrm{O}_{2}=0,0.5,0.75,1,1.25,1.5$ ) and reaction temperature $60^{\circ} \mathrm{C}$ 
Table 1. oxidation DBT under various reaction conditions in the presence of GO@5-Br(Saldien)VO.

\begin{tabular}{|c|c|c|c|c|c|c|c|}
\hline Entry & $\begin{array}{c}\text { Catalyt } \\
\text { amount }(g / \mathbf{l})\end{array}$ & Temperature $\left({ }^{\circ} \mathrm{C}\right)$ & $\begin{array}{c}\text { Molar ratio } \\
\text { of } \mathrm{O} / \mathrm{S}\end{array}$ & $\begin{array}{c}\text { Formic } \\
\text { acid/ } \mathrm{H}_{2} \mathrm{O}_{2}\end{array}$ & Time(h) & Conversion\% & TON \\
\hline 1 & 2.4 & 30 & 6 & 1 & 2 & $57 \%$ & 343.342 \\
\hline 2 & 2.4 & 60 & 6 & 1 & 2 & $92 \%$ & 554.167 \\
\hline 3 & 2.4 & 70 & 6 & 1 & 2 & $93 \%$ & 560.19 \\
\hline 4 & Without catalyst & 60 & 6 & 1 & 2 & $33.99 \%$ & \\
\hline 5 & 1.2 & 60 & 6 & 1 & 2 & $81.01 \%$ & 975.85 \\
\hline 6 & 4.8 & 60 & 6 & 1 & 2 & $87.57 \%$ & 263.717 \\
\hline 7 & 7.2 & 60 & 6 & 1 & 2 & $81.3 \%$ & 162.96 \\
\hline 8 & 2.4 & 60 & 2 & 1 & 2 & $55.92 \%$ & 335.594 \\
\hline 9 & 2.4 & 60 & 4 & 1 & 2 & $79.34 \%$ & 476.145 \\
\hline 10 & 2.4 & 60 & 6 & 1 & 2 & $91.54 \%$ & 549.362 \\
\hline 11 & 2.4 & 60 & 8 & 1 & 2 & $94.37 \%$ & 568.443 \\
\hline 12 & 2.4 & 60 & 10 & 1 & 2 & $94.56 \%$ & 569.587 \\
\hline 13 & 2.4 & 60 & 10 & 0 & 2 & $61.43 \%$ & 368.661 \\
\hline 14 & 2.4 & 60 & 10 & 0.5 & 2 & $90.78 \%$ & 544.801 \\
\hline 15 & 2.4 & 60 & 10 & 0.75 & 2 & $93.11 \%$ & 558.784 \\
\hline 16 & 2.4 & 60 & 10 & 1.25 & 2 & $94.6 \%$ & 567.726 \\
\hline 17 & 2.4 & 60 & 10 & 1.5 & 2 & $96.92 \%$ & 581.649 \\
\hline
\end{tabular}

$\mathrm{TON}=(\%$ conv $) \times($ substrate moles $) /$ catalyst $($ vanadium $)$ moles.

cy. ${ }^{49}$ As shown in Fig. 11, when formic acid (formic acid/ $\mathrm{H}_{2} \mathrm{O}_{2}=1.5$ ) is added to the reaction, in the first $5 \mathrm{~min}$ of the reaction, more than $90 \%$ of the DBT was oxidized, but in the other reaction without the presence of formic acid, in the first $5 \mathrm{~min}$ of the reaction only $27 \%$ of DBT was oxidized. Table 1 shows the DBT oxidation under various reaction conditions in the presence of GO@5-Br(Saldien) VO.

Table 2 shows the comparison of the catalytic activity of GO@5-Br(Saldien)VO with that of other reported catalysts. The results indicated that of GO@5-Br(Saldien)VO was quite reliable for ODS in comparison with other catalysts.

Table 2. Effect of different catalysts in oxidation desulfurization of dibenzothiophene compound.

\begin{tabular}{|c|c|c|c|c|}
\hline Entr & Catalyst & Conversion $\%$ & Reaction condition & Ref \\
\hline 1 & GO@ (5-Br, Saldien) VO & $96.92 \%$ & $\begin{array}{l}5 \mathrm{ml} \text { of model fuel ( } 500 \mathrm{ppm} \text { of DBT in n-heptane), } 2.4 \mathrm{~g} / \mathrm{l} \\
\text { of catalyst, } \mathrm{O} / \mathrm{S}=10 \text {, formic acid } / \mathrm{H}_{2} \mathrm{O}_{2}=1.5, \\
\text { acetonitrile }=5 \mathrm{ml} \text { at } 60^{\circ} \mathrm{C} \text { for } 2 \mathrm{~h}\end{array}$ & This work \\
\hline $2 \mathrm{I}$ & PS- $\left[\mathrm{V}^{\mathrm{IV}} \mathrm{O}(\text { fsal-dmen })(\mathrm{MeO})\right]^{*}$ & $87.9 \%$ & $\begin{array}{l}\mathrm{DBT}(500 \mathrm{ppm}) \text { in } \mathrm{n} \text {-heptane, } \mathrm{O} / \mathrm{S}=3 \text {, catalyst: } \\
0.0715 \mathrm{mmol} \text {, at } 60^{\circ} \mathrm{C} \text {, for } 2 \mathrm{~h}\end{array}$ & 26 \\
\hline 3 & PS-[V $\mathrm{V}^{\mathrm{V}} \mathrm{O}_{2}($ fsal-dmen $\left.)\right]^{\star *}$ & $98.4 \%$ & & \\
\hline 4 pol & ly[VO-(allylSB-co-EGDMA)] $]^{* * *}$ & $99 \%$ & $\begin{array}{l}\text { Flow rate of } 1 \mathrm{ml} / \mathrm{h}, \mathrm{t}-\mathrm{BuOOH} / \mathrm{S}=6.8 \text {, an aqueous } \\
\text { solution of tert-butylhydroperoxide }(\mathrm{t}-\mathrm{BuOOH}) \\
\text { and dibenzothiophene }(\mathrm{DBT}) \text {, were dissolved } \\
\text { in } 10 \mathrm{ml} \text { solution of toluene/hexane }(1: 4) \text {. at } 40^{\circ} \mathrm{C}\end{array}$ & 23 \\
\hline 5 & poly[VO(sal-AHBPD) $]^{* * * *}$ & $88 \%$ & $\begin{array}{l}\text { TBHP }]=0.5 \mathrm{~g}(5.5 \mathrm{mmol}),[\text { dibenzothiophene }]=0.15 \mathrm{~g} \\
(0.814 \mathrm{mmol}), \text { catalyst }=0.015 \mathrm{~g}(0.0135 \mathrm{mmol}) . \\
\text { Temp. }=40^{\circ} \mathrm{C} \text {. Toluene-hexane }(1: 4)=10 \mathrm{ml} \text { for } 2 \mathrm{~h} .\end{array}$ & 50 \\
\hline
\end{tabular}




\section{7. Catalyst Reusability}

The graphene oxide bounded oxovanadium Schiff base catalyst was reused six times for the oxidative desulfurization of DBT under similar oxidation conditions. After each catalytic run, the reaction mixture centrifuged and the used catalyst was recovered by washing with fresh acetonitrile and dried. The fresh model fuel, $\mathrm{H}_{2} \mathrm{O}_{2}$, and formic acid were then added to start a new cycle. At the end of each cycle, samples were taken and analyzed by UVvis and DBT removal is observed. Results showed that the catalytic activity is nearly maintained during the recycling performance.

The results of the ODS reactions using the reused GO@ (5-Br, Saldien)VO after six reuse presented in Table 3. The FT-IR spectrum of the recovered GO@ (5-Br, Saldien) $\mathrm{VO}$ after the sixth run confirmed no significant change in the structure of the catalyst (Fig. 12).

To determine whether the reaction is truly carried out in a heterogeneous way or not, hot filtration test was

Table 3. Reuse of the synthesized catalyst for ODS reaction

\begin{tabular}{cc}
\hline Run & DBT oxidation\% \\
\hline 1 & $96.92 \%$ \\
2 & $93.23 \%$ \\
3 & $91.30 \%$ \\
4 & $91.08 \%$ \\
5 & $91.04 \%$ \\
6 & $86.83 \%$ \\
\hline
\end{tabular}

Conditions of ODS: $5 \mathrm{ml}$ of model fuel (500 ppm of DBT), $2.4 \mathrm{~g}$ $/ 1$ of catalyst, $\mathrm{O} / \mathrm{S}=10$, formic acid $/ \mathrm{H}_{2} \mathrm{O}_{2}=1.5$, acetonitrile $=5 \mathrm{ml}$ for $2 \mathrm{~h}$ at $60^{\circ} \mathrm{C}$.

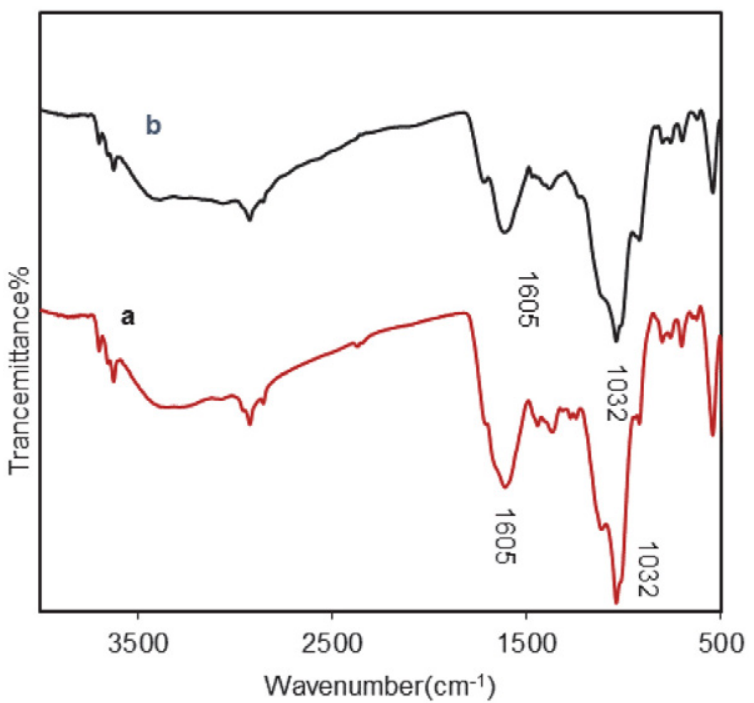

Fig. 12. FT-IR spectrum of (a) GO@5-Br(Saldien)VO and (b) sixth recovered GO@5-Br(Saldien)VO, $5 \mathrm{ml}$ of model fuel (500 ppm of DBT), $2.4 \mathrm{~g} / \mathrm{l}$ of catalyst, $\mathrm{O} / \mathrm{S}=10$, formic acid $/ \mathrm{H}_{2} \mathrm{O}_{2}=1.5$, acetonitrile $=5 \mathrm{ml}$, for $2 \mathrm{~h}$ at $60^{\circ} \mathrm{C}$. investigated. ${ }^{51}$ The result is as follows. In the $15 \mathrm{~min}$ of the reaction process the reaction media were filtered in hot condition. The catalyst remained on the filter paper and the filtrate came through. In the next step the reaction was continued. It was found that the conversion remained the same of the filtrate. This showed that there was no leaching of the immobilized Schiff base complex. Thus, this confirms that the synthesized catalyst acts heterogeneously.

\section{8. Product Characterization}

Oxidative desulfurization reaction in the presence of an oxidant occurs through two consecutive stages. ${ }^{52}$ At the first stage, DBT is oxidized to dibenzothiophene sulfoxide (DBTO), and then, the formed DBTO is rapidly converted to $\mathrm{DBTO}_{2} \cdot{ }^{53}$ The FT-IR spectrum of the produced crystal is shown in Fig. 13. The oxidation product was further proven to be the dibenzothiophene sulfone $\left(\mathrm{DBTO}_{2}\right)$ by FT-IR (characteristic peaks at 1288 and $1165 \mathrm{~cm}^{-1}$ ) that can be attributed to the asymmetrical and symmetrical stretching vibration modes of $\mathrm{O}=\mathrm{S}=\mathrm{O}$, respectively. ${ }^{54}$

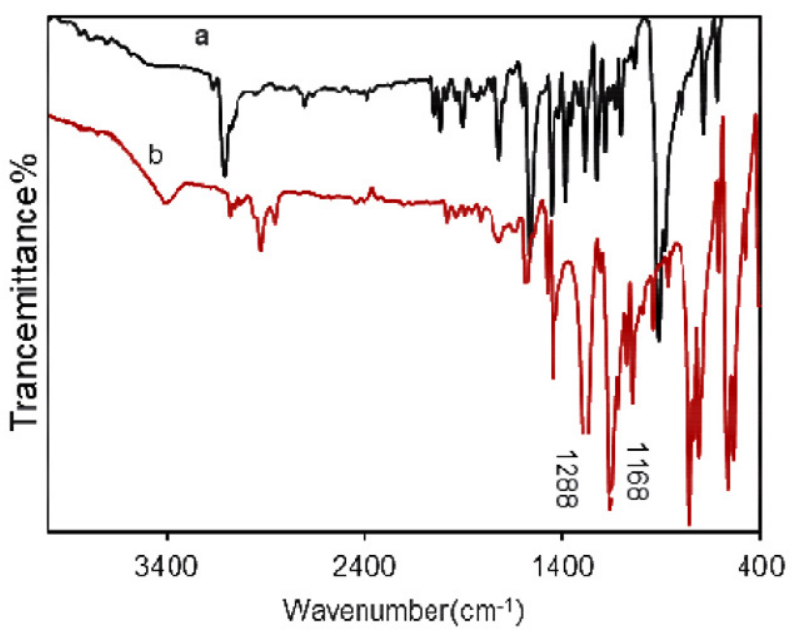

Fig. 13. FT-IR spectrum of the sulfur compound (a) before and (b) after desulfurization reaction.

\section{Conclusions}

New heterogeneous catalyst was synthesized by covalent anchoring of the oxovanadium Schiff base on the graphene oxide support previously functionalized with 3-chloropropyltrimethoxysilane. XRD, FTIR, TG, DTA, SEM, EDX and ICP-AES analyses revealed well loading of the oxovanadium Schiff base complex on the functionalized graphene oxide. The developed catalyst was found to be highly efficient for oxidation desulfurization of model oil using $\mathrm{H}_{2} \mathrm{O}_{2}$ as an oxidant and formic acid as a promoter. The effects of the main process variables such as temperature, catalyst mass, oxygen to sulfur ratio $(\mathrm{O} / \mathrm{S})$ and formic acid $/ \mathrm{H}_{2} \mathrm{O}_{2}$ ratio were inspected using experimental 
design. As a result, a nearly complete oxidative desulfurization was obtained in the optimum condition of $60{ }^{\circ} \mathrm{C}$, an $\mathrm{O} / \mathrm{S}$ ratio of 10 , and a formic acid/ $/ \mathrm{H}_{2} \mathrm{O}_{2}$ ratio of 1.5 in a $120 \mathrm{~min}$ and low catalyst loading $(2.4 \mathrm{~g} / \mathrm{L})$. Moreover, the developed catalyst was found to be easily recoverable and recyclable and could be reused for five subsequent runs.

\section{Acknowledgments}

The authors are grateful to the Research Council of the University of Kurdistan and the University of Guilan for the partial support of this study.

\section{References}

1. X. Xiao, H. Zhong, C. Zheng, M. Lu, X. Zuo, J. Nan, Chem. Eng. J. 2016, 304, 908-916. DOI:10.1016/j.cej.2016.07.022

2. M. I. S. de Mello, E. V. Sobrinho, V. Teixeira da Silva, S. B. C. Pergher, Ind. Eng. Chem. Res. 2018, 57, 15663-15669.

DOI:10.1021/acs.iecr.8b03232

3. C. Song, X. Ma, Appl Catal B. 2003, 41, 207-238.

DOI:10.1016/S0926-3373(02)00212-6

4. B. Pawelec, R. M. Navarro, J. M. Campos-Martin, J. L. G. Fierro, Catal. Sci. Technol 2011, 1, 23-42.

DOI:10.1039/c0cy00049c

5. A. F. Shojaei, M. A. Rezvani, M. H. Loghmani, Fuel Process. Technol. 2014, 118, 1-6. DOI:10.1016/j.fuproc.2013.08.004

6. S. Otsuki, T. Nonaka, N. Takashima, W. Qian, A. Ishihara, T. Imai, T. Kabe, Energy Fuels 2000, 14, 1232-1239.

DOI:10.1021/ef000096i

7. Y. Shiraishi, K. Tachibana, T. Hirai, I. Komasawa, Ind. Eng. Chem. Res. 2002, 41, 4362-4375.

DOI:10.1021/ie010618x

8. A. Srivastav, V. C. Srivastava, J. Hazard. Mater. 2009, 170, 1133-1140. DOI:10.1016/j.jhazmat.2009.05.088

9. Z. Hasan, J. Jeon, S. H. Jhung, J. Hazard. Mater. 2012, 205206, 216-221. DOI:10.1016/j.jhazmat.2011.12.059

10. C. Song, Catal. Today 2003, 86, 211-263. DOI:10.1016/S0920-5861(03)00412-7

11. S. Dhir, R. Uppaluri, M. K. Purkait, J. Hazard. Mater. 2009, 161, 1360-1368. DOI:10.1016/j.jhazmat.2008.04.099

12. C. Shen, Y. Wang, J. Xu, G. Luo, Green Chem. 2016, 18, 771781. DOI:10.1039/C5GC01653C

13. L. A. Gonzalez, P. Kracke, W. H. Green, J. W. Tester, L. M. Shafer, M. T. Timko, Energy Fuels 2012, 26, 5164-5176. DOI:10.1021/ef201289r

14. D. Huang, Z. Zhai, Y. C. Lu, L. M. Yang, G. S. Luo, Ind. Eng. Chem. Res. 2007, 46, 1447-1451. DOI:10.1021/ie0611857

15. J. Luis García-Gutiérrez, G. A. Fuentes, M. Eugenia Hernández-Terán, P. García-Gutiérrez, F. Murrieta-Guevara, J. L. Garcia-Gutierrez, Appl. Catal., A 2008, 334, 366-373.

DOI:10.1016/j.apcata.2007.10.024

16. W. Zhu, G. Zhu, H. Li, Y. Chao, M. Zhang, D. Du, Q. Wang, Z. Zhao, Fuel Process. Technol. 2013, 106, 70-76.

DOI:10.1016/j.fuproc.2012.07.003
17. A. Chica, A. Corma, M. E. Dómine, J. Catal. 2006, 242, 299308. DOI:10.1016/j.jcat.2006.06.013

18. K. Yazu, M. Makino, K. Ukegawa, Chem. Lett. 2004, 33, 13061307. DOI: $10.1246 / \mathrm{cl} .2004 .1306$

19. W. Zhang, H. Liu, Q. Xia, Z. Li, Chem. Eng. J. 2012, 209, 597600. DOI:10.1016/j.cej.2012.08.050

20. J. A. L. da Silva, J. J. R. F. da Silva, A. J. L. Pombeiro, Coordin Chem Rev 2011, 255, 2232-2248.

DOI:10.1016/j.ccr.2011.05.009

21. A. Coletti, P. Galloni, A. Sartorel, V. Conte, B. Floris, Catal. Today 2012, 192, 44-55. DOI:10.1016/j.cattod.2012.03.032

22. L. Kuznetsova, L. Detusheva, N. Kuznetsov, V. Duplyakin, V. Likholobov, Kinet. Catal. 2008, 49, 644-652.

DOI:10.1134/S002315840805008X

23. A. S. Ogunlaja, R. S. Walmsley, C. du Sautoy, N. Torto, Z. R. Tshentu, Energy Fuels 2013, 27, 7714-7723.

DOI:10.1021/ef401708f

24. M. Zhou, W. Meng, Y. Li, Q. Wang, X. Li, S. Zang, Energy Fuels 2013, 28, 516-521. DOI:10.1021/ef402103e

25. D. Piccinino, I. Abdalghani, G. Botta, M. Crucianelli, M. Passacantando, M. L. Di Vacri, R. Saladino, Appl Catal B-Environ. 2017, 200, 392-401. DOI:10.1016/j.apcatb.2016.07.037

26. M. R. Maurya, A. Arya, A. Kumar, M. L. Kuznetsov, F. Avecilla, J. Costa Pessoa, Inorg. Chem. 2010, 49, 6586-6600. DOI:10.1021/ic1004209

27. S. Guo, S. Sun, J. Am. Chem. Soc. 2012, 134, 2492-2495. DOI:10.1021/ja2104334

28. H. P. Mungse, S. Verma, N. Kumar, B. Sain, O. P. Khatri, J. Mater. Chem. 2012, 22, 5427-5433. DOI:10.1039/c2jm15644j

29. S. Verma, M. Aila, S. Kaul, S. L. Jain, RSC Adv. 2014, 4, 3059830604. DOI:10.1039/C4RA03454F

30. Z. Hajjar, M. Kazemeini, A. Rashidi, M. Bazmi, Fuel 2016, 165, 468-476. DOI:10.1016/j.fuel.2015.10.040

31. W. Coleman, L. Taylor, Inorg. Chem 1971, 10, 2195-2199. DOI:10.1021/ic50104a021

32. M. A. Nasseri, A. Allahresani, H. Raissi, RSC Adv. 2014, 4, 26087-26093. DOI:10.1039/c4ra03047h

33. K. Krishnamoorthy, M. Veerapandian, K. Yun, S.-J. Kim, Carbon 2013, 53, 38-49. DOI:10.1016/j.carbon.2012.10.013

34. H. Naeimi, Z. Ansarian, Appl. Organomet. Chem. 2017, 31, e3796. DOI:10.1002/aoc.3796

35. Z. Li, S. Wu, H. Ding, H. Lu, J. Liu, Q. Huo, J. Guan, Q. Kan, New J. Chem. 2013, 37, 4220-4229.

DOI:10.1039/c3nj00982c

36. D. C. Marcano, D. V. Kosynkin, J. M. Berlin, A. Sinitskii, Z. Sun, A. Slesarev, L. B. Alemany, W. Lu, J. M. Tour, ACS nano 2010, 4, 4806-4814. DOI:10.1021/nn1006368

37. A. M. Rodriguez, P. V. Jiménez, Thermochim Acta 1984, 78, 113-122. DOI:10.1016/0040-6031(84)87138-5

38. H. Raghubanshi, S. M. Ngobeni, A. O. Osikoya, N. D. Shooto, C. W. Dikio, E. B. Naidoo, E. D. Dikio, R. K. Pandey, R. Prakash, Ind Eng Chem 2017, 47, 169-178.

DOI:10.1016/j.jiec.2016.11.028

39. H. Su, Z. Li, Q. Huo, J. Guan, Q. Kan, RSC Adv. 2014, 4, 9990 9996. DOI:10.1039/C4RA01812E 
40. U. Arellano, J. Wang, M. Timko, L. Chen, S. P. Carrera, M. Asomoza, O. G. Vargas, M. Llanos, Fuel 2014, 126, 16-25. DOI:10.1016/j.fuel.2014.02.028

41. H. Yang, B. Jiang, Y. Sun, L. Zhang, Z. Sun, J. Wang, X. Tantai, Chem. Eng. J. 2017, 317, 32-41. DOI:10.1016/j.cej.2017.01.135

42. A. K. Dizaji, H. R. Mortaheb, B. Mokhtarani, Chem. Eng. J. 2018, 335, 362-372. DOI:10.1016/j.cej.2017.10.129

43. M. d. C. Capel-Sanchez, P. Perez-Presas, J. M. Campos-Martin, J. Fierro, Catal. Today 2010, 157, 390-396.

DOI:10.1016/j.cattod.2010.01.047

44. J. Zhang, A. Wang, X. Li, X. Ma, J. Catal. 2011, 279, 269-275. DOI:10.1016/j.jcat.2011.01.016

45. V. Mošovský, Z. Cvengrošová, A. Kaszonyi, M. Králik, M. Hronec, Collect. Czech. Chem. Commun. 1996, 61, 14571463. DOI:10.1135/cccc19961457

46. M. A. Rezvani, S. Khandan, Appl. Organomet. Chem. 2018, 32, e4524. DOI:10.1002/aoc.4524

47. J. Xiong, W. Zhu, W. Ding, L. Yang, M. Zhang, W. Jiang, Z.
Zhao, H. Li, RSC Adv. 2015, 5, 16847-16855.

DOI:10.1039/C4RA14382E

48. I. Arends, R. Sheldon, Appl. Catal., A 2001, 212, 175-187. DOI:10.1016/S0926-860X(00)00855-3

49. U. Arellano, Z. Wang, L. Chen, J. A. Wang, M. Asomoza, A. Estrella, Ind. Eng. Chem. Res. 2017, 56, 12080-12091.

DOI:10.1021/acs.iecr.7b02787

50. A. S. Ogunlaja, W. Chidawanyika, E. Antunes, M. A. Fernandes, T. Nyokong, N. Torto, Z. R. Tshentu, Dalton Trans. 2012, 41, 13908-13918. DOI:10.1039/c2dt31433a

51. H. Lempers, R. Sheldon, J. Catal. 1998, 175, 62-69. DOI:10.1006/jcat.1998.1979

52. E. Torres-García, A. Galano, G. Rodriguez-Gattorno, J. Catal. 2011, 282, 201-208. DOI:10.1016/j.jcat.2011.06.010

53. M. Y. Masoomi, M. Bagheri, A. Morsali, Inorg. Chem. 2015, 54, 11269-11275. DOI:10.1021/acs.inorgchem.5b01850

54. L. Hao, L. Sun, T. Su, D. Hao, W. Liao, C. Deng, W. Ren, Y. Zhang, H. Lü, Chem. Eng. J. 2019, 358, 419-426.

DOI:10.1016/j.cej.2018.10.006

\section{Povzetek}

Sintetizirali smo nov heterogeni katalizator preko kovalentnega sidranja oksovanadijevega(IV) kompleksa s 5,5'-dibromobis(salicileden)dietilenetriaminom (VO[5-Br(Saldien)]) na površino kloro-modificiranega grafen oksida (GO@ CTS). Strukturo katalizatorja smo proučevali z uporabo različnih karakterizacijskih tehnik, kot so XRD, SEM, EDX, FT-IR, TG, DTA in ICP-AES analize. Sintetiziran heterogeni oksovanadijev(IV) katalizator je učinkovit katalizator za selektivno oksidacijo in desulfurizacijo (ODS) dibenzotiofena (DBT) kot modela $\mathrm{z}$ uporabo $\mathrm{H}_{2} \mathrm{O}_{2}$ kot oksidanta in mravljinčno kislino kot promotorja. Proučili smo tudi vpliv mase katalizatorja, reakcijske temperature in časa, razmerja $\mathrm{HCOOH} / \mathrm{H}_{2} \mathrm{O}_{2}$ in molskega razmerja $\mathrm{H}_{2} \mathrm{O}_{2}$ glede na celokupno količino žvepla $(\mathrm{O} / \mathrm{S})$ na učinkovitost oksidacije in desulfurizacije. Pripravljeni katalizator je enostavno ločiti iz reakcijske zmesi in ponovno uporabiti šestkrat brez opaznega zmanjšanja katalitske aktivnosti in selektivnosti.

Except when otherwise noted, articles in this journal are published under the terms and conditions of the Creative Commons Attribution 4.0 International License 